\title{
Assessment of the susceptibility of various strains of white button mushroom to Pseudomonas tolaasii
}

\section{Ocena wrażliwości wybranych ras pieczarki dwuzarodnikowej na bakterie Pseudomonas tolaasii}

\author{
Joanna Szumigaj-Tarnowska, Zbigniew Uliński, Jan Szymański
}

\begin{abstract}
Summary
The aim of the research was to assess various strains of white button mushrooms (Agaricus bisporus) susceptibility to brown blotch caused by Pseudomonas tolaasii bacteria. The mushroom strains used in this study are distinguished in size of cups. The investigated mushrooms were characterized by cup size in the following categories: intermediate between large and medium size, medium size and small size. Mushroom crop was infected with suspension containing different concentrations of bacterium cells. The susceptibility to brown blotch of $A$. bisporus was assessed on the basis of healthy and infected mushroom yield in the first and second flush. An inoculum concentration of $2.6 \times 10^{6}$ bacterium cells per $\mathrm{m}^{2}$ casing resulted in a significant yield reduction of healthy mushrooms. The most susceptible to bacterial blotch were the mushroom strain P23, characterized by a small size of cups, and F60 characterized by intermediate between large and medium sized of cups, what resulted in the high yield of infected mushrooms, respectively, in the first and the second flush.
\end{abstract}

Key words: brown blotch, Pseudomonas tolaasii, Agaricus bisporus, bacterial disease, strain of white button mushrooms

\begin{abstract}
Streszczenie
Badania miały na celu określenie podatności różnych ras białej pieczarki dwuzarodnikowej (Agaricus bisporus) na plamistość brunatną wywoływaną przez bakterie Pseudomonas tolaasii. Materiałem badawczym było 5 ras pieczarki, tj. rasa pośrednia między wielko- a średnioowocnikową, średnioowocnikowa i drobnoowocnikowa. Badania prowadzono w warunkach in vivo, które polegały na sztucznym zakażaniu upraw pieczarki zawiesiną bakterii o różnej koncentracji komórek. Podatność na chorobę określano na podstawie plonu owocników zdrowych i porażonych w pierwszym i drugim rzucie owocników. Istotnie zmniejszenie plonu owocników zdrowych nastąpiło po zainfekowaniu uprawy komórkami $P$. tolaasii w liczbie $2,6 \times 10^{6}$ na $\mathrm{m}^{2}$ okrywy. Najbardziej wrażliwą na chorobę bakteryjną okazała się rasa drobnoowocnikowa P23 i pośrednia między wielko- a średnioowocnikową F60, o czym świadczył wysoki plon owocników porażonych, odpowiednio, w I rzucie i w II rzucie.
\end{abstract}

Słowa kluczowe: plamistość brunatna, Pseudomonas tolaasii, Agaricus bisporus, choroba bakteryjna, rasa pieczarki

\footnotetext{
Instytut Ogrodnictwa

Samodzielna Pracownia Grzybów Uprawnych

Rybickiego 15/17, 96-100 Skierniewice

joanna.tarnowska@inhort.pl
} 


\section{Wstęp / Introduction}

Polska, produkując ponad 250 tys. ton pieczarek, jest największym producentem pieczarki w Europie, a także największym eksporterem pieczarki świeżej na świecie (Smoleński 2012). Uważa się, że produkcja tych grzybów ciagle rośnie, w związku z czym rosną również wymagania jakościowe pieczarek (Sakson 2012). Jednym z problemów, z którymi spotyka się branża pieczarkarska są choroby bakteryjne pieczarki, będące przyczyną strat zarówno ilościowych, jak i jakościowych w jej uprawie. Najczęściej pojawiającą się chorobą bakteryjną jest plamistość brunatna wywoływana przez Pseudomonas tolaasii (Soler-Rivas i wsp. 1999). Objawami choroby są ciemnobrązowe, wklęsłe plamy na kapeluszach, które mogą pojawić się w każdym stadium rozwojowym, przy czym porażenie zawiązków owocników może spowodować zahamowanie rozwoju grzybów. Grzyby stają się ciemne, śliskie i nie rozwijają się prawidłowo (Fletcher 1979; Szumigaj i Szymański 2009). Bakterie P. tolaasii mogą porażać wiele gatunków grzybów i roślin, między innymi boczniaka ostrygowatego Pleurotus ostreatus, grzyby shiitake Lentinula edodes, a także pieczarkę czterozarodnikową Agaricus bitorquis (Soler-Rivas i wsp. 1999). Gatunek ten jest zdolny do przechodzenia $\mathrm{z}$ formy niepatogenicznej (saprofitycznej) w patogeniczna, co zostało potwierdzone przez Cutri i wsp. (1984). Takie uzdolnienia pozwalają $P$. tolaasii zasiedlać różne, często ubogie w składniki odżywcze, środowiska. W zależności od formy występowania, bakterie tworzą kolonie opalizujące o gładkich brzegach, wytwarzające śluz i toksynę (forma patogeniczna) lub kolonie szorstkie, przejrzyste oraz nie wytwarzające śluzu (forma saprofityczna) (Cutri i wsp. 1984).

Rozwojowi choroby sprzyjają przede wszystkim: wysoka wilgotność powietrza w hali uprawowej, pozostawiona woda na owocnikach, a także wysoka temperatura. Szybkie osuszenie owocników, w ciągu dwóch godzin, po zabiegu podlewania powinno chronić przed infekcją (Gandy 1967).

$\mathrm{Z}$ dostępnej literatury wynika, że rasy pieczarki białej nie są odporne na porażenie przez chorobotwórcze bakterie z rodzaju Pseudomonas, jedynie pewną odporność wykazują rasy dzikie i pieczarka brązowa (Soler-Rivas i wsp. 1999). Prawdopodobnie skład grzybów i ich uwarunkowania genetyczne mogą wpływać na różną podatność ras pieczarki na chorobę. Między innymi Mamoun i wsp. (1999) zajmowali się określeniem wpływu warunków środowiskowych na podatność pieczarki na chorobę bakteryjną. Stwierdzili, że różna podatność ras pieczarki zależy od warunków środowiska, a zwłaszcza jakości kompostu. Ponadto analiza aktywności enzymów pieczarki, tj. transferaza $\gamma$-glutamylowa oraz $\gamma$-glutaminylo-4-hydrobenzen wykazała, że determinują one podatność tych grzybów na porażenie przez chorobotwórcze bakterie. Aktywność tyrozynazy nie ma wpływu na podatność pieczarki na infekcje bakteryjne (Largeteau i Savoie 2010).

Celem badań było określenie podatności różnych ras pieczarki dwuzarodnikowej (Agaricus bisporus) na plamistość brunatną wywoływaną przez bakterię $P$. tolaasii.

\section{Materiały i metody / Materials and methods}

Materiałem badawczym było 5 ras pieczarki dwuzarodnikowej należących do grupy pośredniej między wielkoa średnioowocnikową, średnioowocnikowa oraz drobnoowocnikowa. Badane rasy zostały oznaczone jako: F60, AM - rasy pośrednie między wielko- a średnioowocnikową, A15, P30 - rasy średnioowocnikowe oraz P23 - rasa drobnoowocnikowa.

Doświadczenie prowadzono w klimatyzowanych halach, w doniczkach $\mathrm{z}$ podłożem pieczarkowym fazy II, do którego wsiewano odpowiednią grzybnię pieczarki w ilości $7 \mathrm{~g} / \mathrm{kg}$ podłoża. Podłoże po wymieszaniu z grzybnią umieszczano w ilości $1,7 \mathrm{~kg}$ w donicach o średnicy $220 \mathrm{~mm}$. Próby inkubowano $\mathrm{w}$ temperaturze $22-23^{\circ} \mathrm{C}$ i wilgotności względnej powietrza 92-94\% przez 14 dni, a następnie na przerośnięte podłoże nakładano warstwę ziemi okrywowej o grubości $40 \mathrm{~mm}$ (pole powierzchni okrywy wynosiło $0,038 \mathrm{~m}^{2}$ ). W dniu nałożenia okrywy przeprowadzono sztuczne zakażanie uprawy zawiesiną komórek $P$. tolaasii LMG 2354 o gęstości komórek $1 \times 10^{4}$, $1 \times 10^{5}$ i $1 \times 10^{6} / \mathrm{ml}$, co warunkowało uzyskanie $2,6 \times 10^{6}$; $2,6 \times 10^{7}$ lub $2,6 \times 10^{8}$ komórek na $\mathrm{m}^{2}$ okrywy. Po przerośnięciu okrywy przez grzybnię pieczarki, w hali obniżono temperaturę do $18-19^{\circ} \mathrm{C}$ oraz stężenie dwutlenku węgla do $800 \mathrm{mg} / \mathrm{l}$. Doświadczenie założono w układzie dwuczynnikowym. Pierwszy czynnik stanowiły różne koncentracje komórek bakterii, a drugi różne rasy pieczarki. Doświadczenie przeprowadzono dwukrotnie w 4 powtórzeniach. $\mathrm{Na}$ podstawie plonu pieczarek zdrowych i porażonych w pierwszym i drugim rzucie określono wrażliwość danej rasy pieczarki na rozwój i nasilenie plamistości bakteryjnej. Różnice między średnimi z prób kontrolnych i badanych porównywano testem NewmanaKeulsa przy $\alpha=0,05$.

\section{Wyniki i dyskusja / Results and discussion}

Do tej pory nie uzyskano rasy pieczarki całkowicie odpornej na plamistość bakteryjna, jedynie rasy pieczarki brązowej i dzikiej wykazują na nią pewną odporność (Soler-Rivas i wsp. 1999). Badania również wykazały, że wszystkie badane rasy były porażane przez $P$. tolaasii. W zależności od rasy pieczarki plon owocników w pierwszym rzucie w próbach kontrolnych kształtował się od 13,5 do $15,8 \mathrm{~kg}$ na $\mathrm{m}^{2}$ okrywy (tab. 1). Zainfekowanie uprawy komórkami $P$. tolaasii w liczbie $2,6 \times 10^{6}$ na $\mathrm{m}^{2}$ okrywy wpłynęło istotnie na zmniejszenie plonu owocników zdrowych, przy czym wrażliwość badanych ras była porównywalna, a plon owocników mieścił się w zakresie od 8,2 do $10,0 \mathrm{~kg} / \mathrm{m}^{2}$. Większa koncentracja komórek bakterii wprowadzona do okrywy powodowała zmniejszanie plonu owocników zdrowych, a zwiększanie liczby owocników z objawami chorobowymi. Najwyższy plon owocników porażonych stwierdzono w przypadku rasy drobnoowocnikowej P23 $\left(11,6 \mathrm{~kg}\right.$ na $\left.\mathrm{m}^{2}\right)$ i średnioowocnikowej P30 (11,1 kg na $\left.\mathrm{m}^{2}\right)$, gdy uprawę zakażono

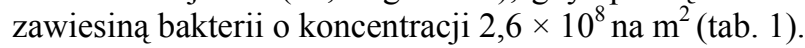




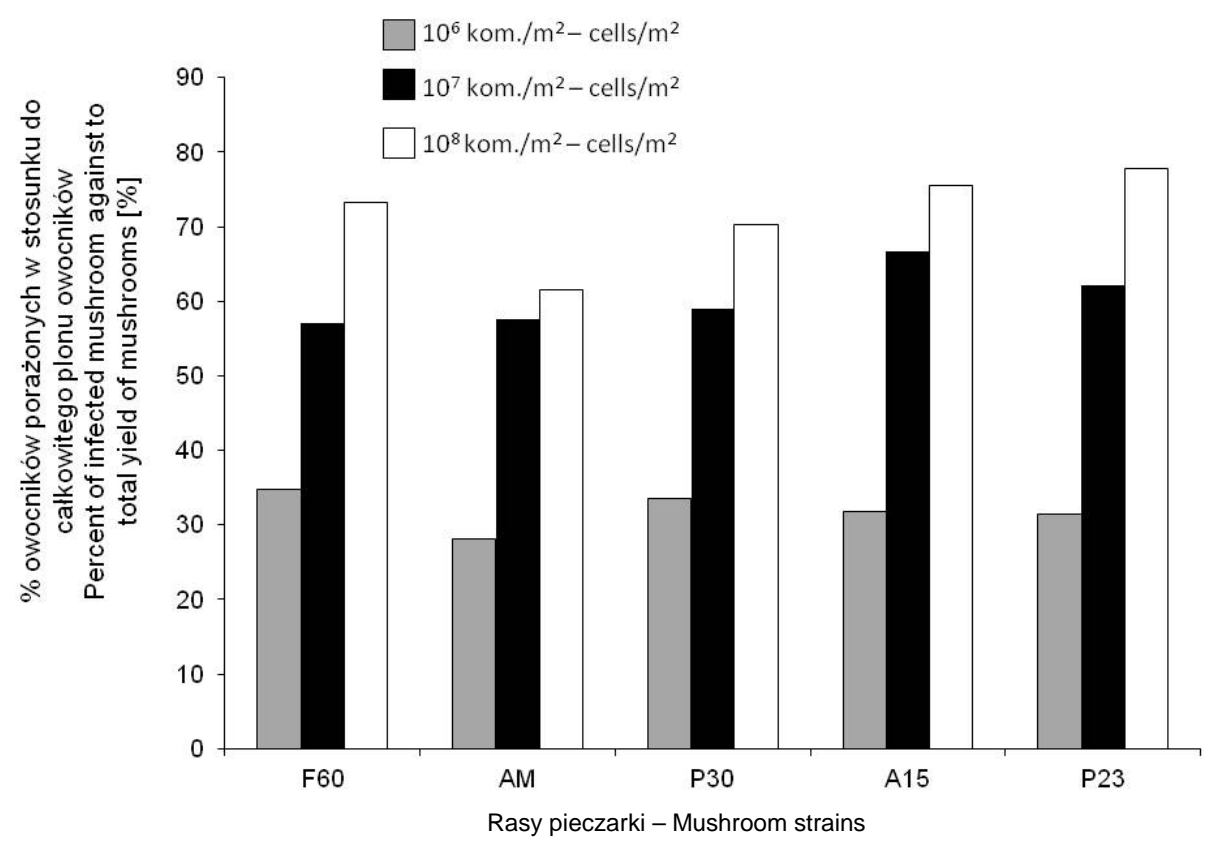

Rys. 1. Procent owocników porażonych w stosunku do całkowitego plonu owocników w pierwszym rzucie Fig. 1. Percent of infected mushrooms against to total yield of mushrooms in the first flush

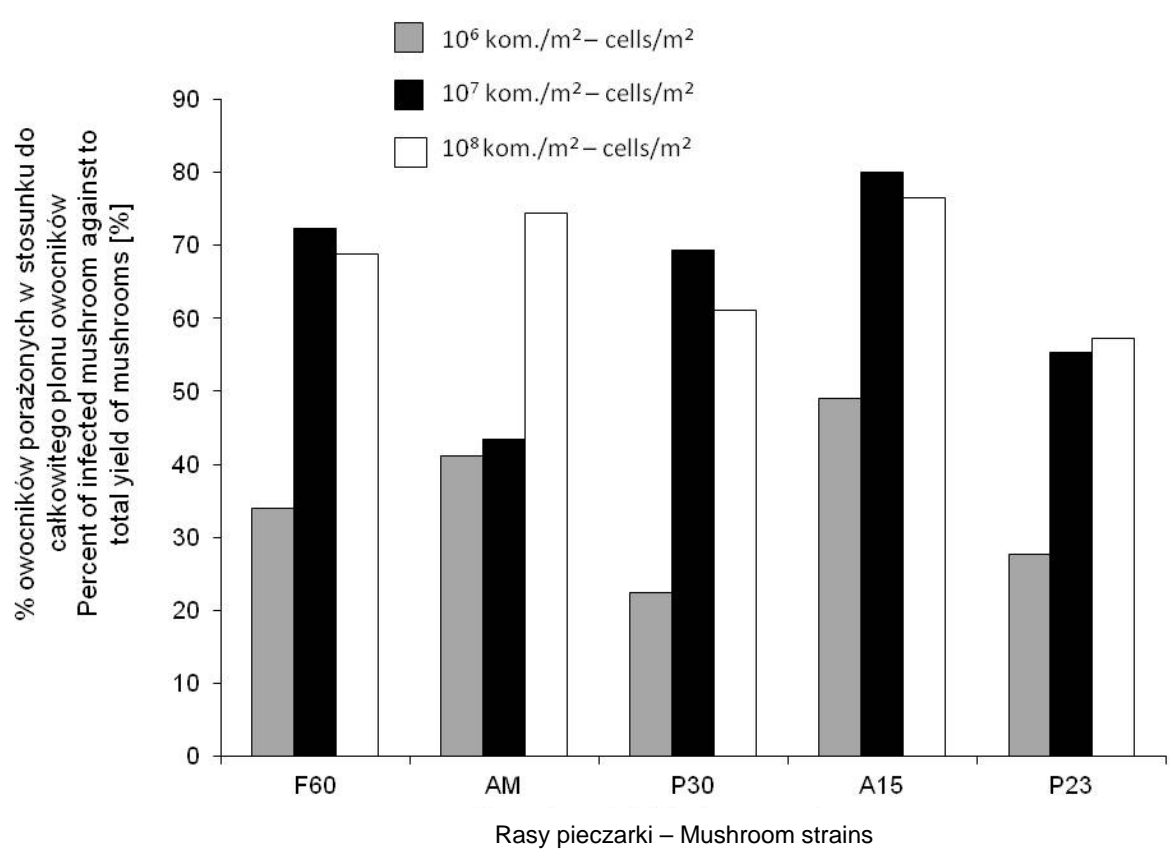

Rys. 2. Procent owocników porażonych w stosunku do całkowitego plonu owocników w drugim rzucie Fig. 2. Percent of infected mushrooms against to total yield of mushrooms in the second flush

Plon owocników porażonych $\mathrm{w}$ stosunku do plonu całkowitego w I rzucie przy infekcji najwyższą koncentracją komórek bakterii $\left(2,6 \times 10^{8} \mathrm{na} \mathrm{m}^{2}\right)$ potwierdzil, że pieczarka rasy P23 była najbardziej wrażliwa na porażenie plamistością brunatną, natomiast najmniej podatna była rasa AM (pomiędzy wielko- a średnioowocnikową) (rys. 1).
W drugim rzucie plon owocników był niższy niż w pierwszym i mieścił się $\mathrm{w}$ zakresie 4,0-6,5 $\mathrm{kg}$ na $\mathrm{m}^{2}$ okrywy w zależności od rasy (tab. 2). Różnice w uzyskanym plonie między badanymi rasami nie były istotne statystycznie. Infekcja uprawy bakteriami w ilości 2,6 $\times 10^{6}$ na $\mathrm{m}^{2}$ nie spowodowała istotnego obniżenia plonu $\mathrm{i}$ był 
Tabela 1. Średni plon owocników $\left[\mathrm{kg} / \mathrm{m}^{2}\right]$ badanych ras pieczarki w pierwszym rzucie w zależności od liczby komórek $P$. tolaasii Table 1. Average yielding $\left[\mathrm{kg} / \mathrm{m}^{2}\right]$ of mushroom strains in the first flush depending on number of $P$. tolaasii cells

\begin{tabular}{|c|c|c|c|c|c|c|}
\hline \multirow{2}{*}{\multicolumn{2}{|c|}{$\begin{array}{l}\text { Liczba komórek [jtk } / \mathrm{m}^{2} \text { okrywy] } \\
\text { Number of cells }\left[\mathrm{cfu} / \mathrm{m}^{2} \text { casing] }\right.\end{array}$}} & \multicolumn{5}{|c|}{ Rasa pieczarki - Mushroom strain } \\
\hline & & F60 & $\mathrm{AM}$ & P30 & A15 & $\mathrm{P} 23$ \\
\hline \multicolumn{2}{|c|}{ Kontrola - Control } & $13,5 \mathrm{~A}^{*} \mathrm{a}^{* *}$ & $14,6 \mathrm{~A} \mathrm{a}$ & $15,8 \mathrm{~A} \mathrm{a}$ & $13,5 \mathrm{~A} \mathrm{a}$ & $14,9 \mathrm{~A} \mathrm{a}$ \\
\hline $2,6 \times 10^{6}$ & $\begin{array}{l}\text { zdrowe - healthy } \\
\text { porażone - infected }\end{array}$ & $\begin{array}{l}8,2 \mathrm{~A} \mathrm{be} \\
4,7 \mathrm{~A} \mathrm{c}\end{array}$ & $\begin{array}{l}8,7 \mathrm{~A} \mathrm{~b} \\
4,1 \mathrm{~A} \mathrm{c}\end{array}$ & $\begin{array}{l}9,3 \mathrm{~A} \mathrm{~b} \\
5,3 \mathrm{~A} \mathrm{c}\end{array}$ & $\begin{array}{l}9,6 \mathrm{~A} \mathrm{~b} \\
4,3 \mathrm{~A} \mathrm{c}\end{array}$ & $\begin{array}{r}10,0 \mathrm{~A} \mathrm{~b} \\
4,7 \mathrm{~A} \mathrm{c}\end{array}$ \\
\hline $2,6 \times 10^{7}$ & $\begin{array}{l}\text { zdrowe - healthy } \\
\text { porażone - infected }\end{array}$ & $\begin{array}{l}4,2 \mathrm{~A} \mathrm{c} \\
7,7 \mathrm{~A} \mathrm{~b}\end{array}$ & $\begin{array}{l}5,3 \mathrm{~A} \mathrm{c} \\
8,4 \mathrm{~A} \mathrm{~b}\end{array}$ & $\begin{array}{l}4,9 \mathrm{~A} \mathrm{c} \\
9,3 \mathrm{~A} \mathrm{~b}\end{array}$ & $\begin{array}{l}4,5 \mathrm{~A} \mathrm{c} \\
9,0 \mathrm{~A} \mathrm{~b}\end{array}$ & $\begin{array}{l}4,4 \mathrm{~A} \mathrm{c} \\
9,3 \mathrm{~A} \mathrm{~b}\end{array}$ \\
\hline $2,6 \times 10^{8}$ & $\begin{array}{l}\text { zdrowe - healthy } \\
\text { porażone - infected }\end{array}$ & $\begin{array}{l}2,9 \mathrm{~A} \mathrm{~d} \\
9,9 \mathrm{AB} \mathrm{e}\end{array}$ & $\begin{array}{l}2,8 \mathrm{~A} \mathrm{~d} \\
9,0 \mathrm{~A} \mathrm{~b}\end{array}$ & $\begin{array}{r}3,1 \mathrm{~A} \mathrm{~d} \\
11,1 \mathrm{~B} \mathrm{e}\end{array}$ & $\begin{array}{c}3,7 \mathrm{Ac} \\
10,2 \mathrm{AB} \mathrm{b}\end{array}$ & $\begin{array}{r}2,4 \mathrm{~A} \mathrm{~d} \\
11,6 \mathrm{~B} \mathrm{e}\end{array}$ \\
\hline
\end{tabular}

* średnie w rzędach, oznaczone tymi samymi dużymi literami, nie różnią się statystycznie przy $\alpha=0,05$ - means in rows, followed by the same capital letters, are not significantly different at $\alpha=0.05$

** średnie w kolumnach, oznaczone tymi samymi małymi literami, nie różnią się statystycznie przy $\alpha=0,05-$ means in columns, followed by the same lower case letters, are not significantly different at $\alpha=0.05$

Tabela 2. Średni plon owocników $\left[\mathrm{kg} / \mathrm{m}^{2}\right]$ badanych ras pieczarki w drugim rzucie w zależności od liczby komórek $P$. tolaasii Table 2. Average yielding $\left[\mathrm{kg} / \mathrm{m}^{2}\right]$ of mushroom strains in the second flush depending on number of $P$. tolaasii cells

\begin{tabular}{|c|c|c|c|c|c|c|}
\hline \multirow{2}{*}{\multicolumn{2}{|c|}{$\begin{array}{l}\text { Liczba komórek [jtk } / \mathrm{m}^{2} \text { okrywy] } \\
\text { Number of cells }\left[\mathrm{cfu} / \mathrm{m}^{2} \text { casing] }\right.\end{array}$}} & \multicolumn{5}{|c|}{ Rasa pieczarki - Mushroom strain } \\
\hline & & F60 & $\mathrm{AM}$ & P30 & A15 & $\mathrm{P} 23$ \\
\hline \multicolumn{2}{|c|}{ Kontrola-Control } & $4,7 \mathrm{~A}^{*} \mathrm{a}^{* *}$ & $5,1 \mathrm{~A} \mathrm{a}$ & $4,9 \mathrm{~A} \mathrm{a}$ & $4,7 \mathrm{~A} \mathrm{a}$ & $6,5 \mathrm{~A} \mathrm{a}$ \\
\hline $2,6 \times 10^{6}$ & $\begin{array}{l}\text { zdrowe - healthy } \\
\text { porażone - infected }\end{array}$ & $\begin{array}{l}3,1 \mathrm{~A} \mathrm{abc} \\
1,6 \mathrm{AB} \mathrm{b}\end{array}$ & $\begin{array}{l}4,5 \mathrm{~A} \mathrm{ab} \\
2,1 \mathrm{AB} \mathrm{c}\end{array}$ & $\begin{array}{l}3,0 \mathrm{~A} \mathrm{ab} \\
1,1 \mathrm{~A} \mathrm{~d}\end{array}$ & $\begin{array}{l}3,7 \mathrm{~A} \mathrm{a} \\
2,3 \mathrm{~B} \mathrm{~b}\end{array}$ & $\begin{array}{l}3,3 \mathrm{~A} \mathrm{a} \\
1,8 \mathrm{AB} \mathrm{b}\end{array}$ \\
\hline $2,6 \times 10^{7}$ & $\begin{array}{l}\text { zdrowe - healthy } \\
\text { porażone - infected }\end{array}$ & $\begin{array}{l}2,2 \mathrm{~A} \mathrm{bc} \\
3,4 \mathrm{~A} \mathrm{ac}\end{array}$ & $\begin{array}{l}2,3 \mathrm{~A} \mathrm{c} \\
2,1 \mathrm{~B} \mathrm{c}\end{array}$ & $\begin{array}{l}2,4 \mathrm{~A} \mathrm{bc} \\
3,4 \mathrm{~A} \mathrm{a}\end{array}$ & $\begin{array}{l}2,7 \mathrm{~A} \mathrm{~b} \\
3,9 \mathrm{~A} \mathrm{a}\end{array}$ & $\begin{array}{l}2,1 \mathrm{~A} \mathrm{~b} \\
3,6 \mathrm{~A} \mathrm{a}\end{array}$ \\
\hline $2,6 \times 10^{8}$ & $\begin{array}{l}\text { zdrowe - healthy } \\
\text { porażone - infected }\end{array}$ & $\begin{array}{l}1,9 \mathrm{~A} \mathrm{bc} \\
3,0 \mathrm{Ac}\end{array}$ & $\begin{array}{l}2,4 \mathrm{~A} \mathrm{c} \\
3,8 \mathrm{~A} \mathrm{~b}\end{array}$ & $\begin{array}{l}2,1 \mathrm{~A} \mathrm{c} \\
2,8 \mathrm{~A} \mathrm{bc}\end{array}$ & $\begin{array}{l}2,5 \mathrm{~A} \mathrm{~b} \\
3,6 \mathrm{~A} \mathrm{a}\end{array}$ & $\begin{array}{l}1,9 \mathrm{~A} \mathrm{~b} \\
3,6 \mathrm{~A} \mathrm{a}\end{array}$ \\
\hline
\end{tabular}

*średnie w rzędach, oznaczone tymi samymi dużymi literami, nie różnią się statystycznie przy $\alpha=0,05$ - means in rows, followed by the same capital letters, are not significantly different at $\alpha=0.05$

** średnie w kolumnach, oznaczone tymi samymi małymi literami, nie różnią się statystycznie przy $\alpha=0,05-$ means in columns, followed by the same lower case letters, are not significantly different at $\alpha=0.05$

on w zakresie od 3,0 do 4,5 $\mathrm{kg} / \mathrm{m}^{2}$. Istotny spadek plonu owocników zdrowych nastapił, gdy uprawę zainfekowano bakteriami w liczbie $2,6 \times 10^{7}$ na $^{2}$ i wyższej.

Plon owocników z objawami plamistości bakteryjnej przy porażeniu uprawy komórkami bakterii w liczbie $2,6 \times 10^{6} \mathrm{jtk} / \mathrm{m}^{2}$ był w zakresie $1,1-2,1 \mathrm{~kg}$ na $\mathrm{m}^{2}$. Wyraźnie wyższy plon tych grzybów zebrano, gdy uprawę porażono bakteriami w ilości $2,6 \times 10^{7} \mathrm{i} 2,6 \times 10^{8} \mathrm{jtk} / \mathrm{m}^{2}$ (tab. 2). Analizując procent owocników porażonych w stosunku do plonu całkowitego w drugim rzucie wykazano, że najbardziej podatne na chorobę bakteryjną były rasy F60 i A15 (rys. 2). W przypadku rasy P23 i P30 stwierdzono, że w drugim rzucie plon owocników porażonych zmniejszył się w stosunku do plonu w rzucie pierwszym (rys. 1, 2).

Z danych literaturowych wynika, że pieczarka biała jest W różnym stopniu podatna na plamistość bakteryjna, natomiast nie istnieje rasa odporna na tę chorobę. Moquet i wsp. (1996) przebadali 115 różnych ras pieczarki i żadna nie była odporna na bakterie $P$. tolaasii. Inne badania wykazały, że pieczarka brązowa jest bardziej odporna na infekcje bakteryjne niż biała (Moquet i wsp. 1998). Parametry uprawy mają wpływ na zróżnicowaną podatność pieczarek na wystąpienie plamistości na kapeluszach.
Olivier i wsp. (1997) wykazali, że owocniki z kolejnych rzutów są bardziej odporne na plamistość bakteryjną, na co wskazywała niższa liczba grzybów z objawami chorobowymi. Podobne wyniki uzyskano w prezentowanych badaniach. Plon owocników porażonych ras P23 i P30 w drugim rzucie był niższy niż w pierwszym. Ponadto wysoki plon owocników zainfekowanych rasy P23 w pierwszym rzucie oraz rasy F60 w drugim rzucie wskazywały na dużą wrażliwość tych ras na porażenie przez $P$. tolaasii. Podobne wyniki uzyskała Szumigaj i wsp. (2011). Rasy P23 i F60 były najbardziej podatne na suchą zgniliznę.

\section{Wnioski / Conclusions}

1. Istotnie zmniejszenie plonu owocników zdrowych nastapiło po zainfekowaniu uprawy bakteriami P. tolaasii w liczbie 2,6 × $10^{6}$ komórek na $\mathrm{m}^{2}$ okrywy.

2. Najbardziej wrażliwa na plamistość bakteryjną była rasa drobnoowocnikowa P23 i pośrednia między wielko- a średnioowocnikową F60, o czym świadczył wysoki plon owocników porażonych, odpowiednio w I rzucie i w II rzucie. 
Praca naukowa finansowana przez Narodowe Centrum

Nauki ze środków na naukę w latach 2008-2011 jako

projekt badawczy nr NN 310315434

\section{Literatura / References}

Cutri S.S., Macauley B.J., Roberts W.P. 1984. Characteristics of pathogenic non-fluorescent (smooth) and non-pathogenic fluorescent (rough) forms of Pseudomonas tolaasii and Pseudomonas gingeri. J. Appl. Bacteriol. 57: 291-298.

Fletcher J.T. 1979. Bacteria and mushrooms. Mush. J. 82: 451-457.

Gandy D.G. 1967. The epidemiology of bacterial blotch of the cultivated mushroom. Rep. Glasshouse Crops Res. Inst. 1966: 150-154.

Largeteau M.L., Savoie J.-M. 2010. Microbially induced diseases of Agaricus bisporus: biochemical mechanisms and impact on commercial mushroom production. Appl. Microbiol. Biotechnol. 86: 63-73.

Mamoun M., Moquet F., Savoie J.M., Devesse C., Ramos-Guedes-Lafargue M., Olivier J.M., Arpin N. 1999. Agaricus bisporus susceptibility to bacterial blotch in relation to environment: biochemical studies. FEMS Microbiol. Lett. 181 (1): 131-136.

Moquet F., Mamoun M., Olivier J.M. 1996. Pseudomonas tolaasii and tolaasin: Comparison of symptom induction on a wide range of Agaricus bisporus strains. FEMS Microbiol. Lett. 142: 99-103.

Moquet F., Mamoun M., Ramos-Guedes-Lafargue M., Olivier J.-M., Savoie J.M. 1998. Differences in susceptibility of Agaricus bisporus strains to bacterial blotch and in natural cap colour related to compost composition. Plant Breeding 117 (4): 385-388.

Olivier J.-M., Mamoun M., Munsch P. 1997. Standarization of a method to assess mushroom blotch resistance in cultivation and wild Agaricus bisporus strains. Can. J. Plant Pathol. 19: 36-42.

Sakson N. 2012. Przemysłowa produkcja pieczarki na rynek świeży. Cz. 2. Biul. Producenta Pieczarek 1: $42-47$.

Soler-Rivas C., Jolivet S., Arpin N., Olivier J.M., Wichers H.J. 1999. Biochemical and physiological aspects of brown blotch disease of Agaricus bisporus. FEMS Microbiol. Rev. 23: 591-614.

Smoleński T. 2012. Eksport pieczarek w I półroczu 2012 r. Biul. Producenta Pieczarek 3: 47-51.

Szumigaj-Tarnowska J., Uliński Z., Ślusarski C., Szymański J. 2011. Podatność wybranych ras pieczarki na grzyb chorobotwórczy Lecanicillium fungicola (Verticillium fungicola). [Susceptibility of the various strains of the cultivated mushrooms to the fungal pathogen Lecanicillium fungicola (Verticillium fungicola)]. Prog. Plant Prot./Post. Ochr. Roślin 51 (3): 1203-1206.

Szumigaj J., Szymański J. 2009. Identyfikacja, mechanizm działania i zwalczanie bakterii patogenicznych dla pieczarki Agaricus bisporus. Post. Nauk Rol. 331 (2): 39-49. 